\title{
Influence of the method of forage conservation on feeding behaviour, intake and characteristics of reticulo-rumen content, in sheep fed ad libitum
}

\author{
V Chiofalo ${ }^{1}$, JP Dulphy 2*, R Baumont 2 \\ with the technical collaboration of $M$ Jailler and JM Ballet \\ 1 Istituto di Zootechnica, Via S, Cecilia 30, 98100 Messina Italy; \\ 2 INRA, CRZV de Theix, Station de Recherches sur la Nutrition des Herbivores, \\ 63122 Saint-Genès-Champanelle, France
}

(Received 10 February 1992; accepted 2 July 1992)

\begin{abstract}
Summary - The influence of silage conservation methods on eating behaviour and the characteristics of reticulo-rumen contents was studied in sheep by comparing 3 forages, a silage without additive (WAS), one with additive (FAS) and hay (H), prepared from the same cut green forage. The sheep were rumen fistulated. WAS was very badly and FAS poorly preserved while the hay was dried under favourable conditions. The forages were fed ad libitum and the dry matter (DM) intake was 1054 , 1241 and $1469 \mathrm{~g} /$ day for WAS, FAS and $\mathrm{H}$ respectively. There was a single feeding in the morning. At the main meal, DM intake was 270,317 and $388 \mathrm{~g} /$ day and ingestion rate $4.76,4.56$ and $4.16 \mathrm{~g}$ of $\mathrm{DM} / \mathrm{min}$ for WAS, FAS and $\mathrm{H}$ respectively. There was slight recovery in ingestion around $16-19 \mathrm{~h}$ with hay and FAS but not with WAS. With hay, rumination lasted much longer than with the silages and began sooner after the end of the main meal. In contrast, overall rumination efficiency was the same for hay and FAS. There were fewer contractions of the reticulo-rumen with both W/S and hay. The amounts of reticulo-rumen contents were comparable for the 2 silages and higher for hay. The amounts of $\mathrm{NH}_{3}$ in the contents were the same with WAS and hay but greater with FAS. With WAS, contents were richer in butyric, valeric and caproic acids. The DM turnover rate of the contents was the same for FAS and hay and lower, but not significantly, for WAS. Accordingly, with silage, satiety seems to be rapidly reached but there was no evidence that organoleptic factors were involved. There were no problems with the digestion rate of silages. However, the factors limiting silage intake persisted throughout the diumal cycle, and reticulo-rumen fill was affected. The more poorly preserved the silage the more these factors reduced the duration and volume of the meals, or both.
\end{abstract}

intake / feeding behaviour / rumen content / forage conservation / sheep

Résumé - Influence de la méthode de conservation du fourrage sur le comportement alimentaire, l'ingestion et les caractéristiques du contenu réticulo-ruminal, chez le mouton nourri à volonté. L'influence du mode de conservation sur les activités alimentaires et les caractéristiques du contenu réticulo-ruminal a été étudié chez le mouton par comparaison de 3 fourrages (un ensilage

\footnotetext{
* Correspondence and reprints
} 
sans conservateur WAS, un ensilage avec conservateur FAS et un foin $H$ ) préparés à partir du même fourrage vert sur pied. Les moutons étaient munis d'une fistule du rumen. L'ensilage WAS a été très mal conservé et l'ensilage FAS a eu une qualité de consenvation médiocre alors que le foin avait été séché très correctement. Dans ces conditions, les quantités de MS ingérées ad libitum ont été respectivement égales à 1054, 1241 et $1469 \mathrm{~g} / \mathrm{j}$. Les fourrages ont été distribués en une seule fois le matin. Lors du grand repas les quantités de MS ingérées ont été de 270,317 et $388 \mathrm{~g} / \mathrm{j}$ alors que les vitesses d'ingestion étaient respectivement de $4,76,4,56$ et $4,16 \mathrm{~g}$ de $\mathrm{MS} / \mathrm{min}$. Au cours de la joumée une très légère reprise de lingestion a été obsenée vers 16-19 h pour le foin, également pour l'ensilage FAS, mais pas pour l'ensilage WAS. Avec le foin, la durée de rumination a été nettement plus élevée qu'avec les ensilages et cette rumination a démarré toujours plus vite après la fin du grand repas. Par contre, l'efficacité globale de la rumination a été la même pour le foin et l'ensilage FAS. II y a eu moins de contractions du réseau avec l'ensilage WAS, mais également avec le foin. Les quantités de contenu du réticulo-rumen ont été comparables pour les 2 ensilages et plus élevées pour le foin. Dans les contenus réticuloruminaux les teneurs en $\mathrm{NH}_{3}$ ont été identiques pour l'ensilage WAS et le foin, mais plus élevées pour l'ensilage FAS. La plus importante augmentation au cours du repas a été observée avec l'ensilage WAS. Avec cet ensilage, les contenus ont été plus riches en acides butyrique, valérianique et caproique. Enfin, le taux de renouvellement de la matière sèche des contenus a été identique pour l'ensilage FAS et le foin et plus faible, mais non significativement, pour l'ensilage WAS. L'ingestion d'ensilage entraine donc un rassasiement rapide des animaux sans que, apparemment, des facteurs organoleptiques ne soient en cause. II n'y a pas non plus de problèmes dans la vitesse de digestion des ensilages. Par contre, les facteurs limitant l'ingestion des ensilages ont un effet permanent tout au long du nycthémère. Cet effet limite le remplissage du réticulo-rumen. Les facteurs en cause réduisent d'autant plus la durée etrou le volume des repas que les ensilages sont plus mal conservés.

\section{ingestion / comportement alimentaire / rumen / conservation de fourrage / mouton}

\section{INTRODUCTION}

In Europe, grass silage is increasingly preferred to hay as animal feed. The variations in intake between these two types of forage depend on how finely they are chopped, how well they are preserved and on their dry matter (DM) content. All these factors have been thoroughly studied (Demarquilly et al, 1981; Dulphy and Michalet-Doreau, 1981; Dulphy and Demarquilly, 1991). However, despite the large number of published reports, the mechanisms involved in the regulation of silage intake have not yet been completely elucidated. Two main approaches, descriptive or experimental, emerge from studies in this field. The first is based essentially on 3 complementary methods of investigation: 1) examination of the regressions between the intake and characteristics of silage (Wilkins et al, 1971; Demarquilly, 1973); 2) observation of eating behaviour (Deswysen et al, 1978; Dulphy et al, 1984); 3) observation of the extent of reticulo-rumen fill (Campling, 1966; Dulphy et al, 1975a; Thiago and Gill, 1986). The second approach is based on the study of the effects of experimental modifications to silage characteristics: chopping of silage after removal from the silo (Dulphy and Demarquilly, 1973) and addition of different acids of nitrogen compounds at the time of feeding (Hutchinson and Wilkins, 1971; Martin Clancy et al, 1977; Buchanan-Smith and Philipp, 1986; Buchanan-Smith, 1990).

In sheep receiving grass silage, the amounts of DM ingested during the main meal after distribution were low (Duiphy, 1985) but this was offset by an increase in the number of small meals taken during the day, if green forage (Dulphy et al, 1984) or hay (Dulphy et al, 1975a) were taken as controls. These findings suggest that the animals did not use their rumen capacity to the full (Thiago and Gill, 1986). 
In the present trial we studied both the behaviour of the animals and the physical as well as the chemical characteristics of ruminal digestion in relation to the nature of the preserved forage. For that purpose we compared 3 preserved forages, all prepared at the same time from the same green plant, but with very different characteristics: poorly preserved silage, well preserved silage and a good hay. Our objective was to try to understand the daily voluntary intake of these 3 forages by the analysis of the kinetics of intake, of the eating and ruminating activities, of the extent of the rumen fill and of the characteristics of reticulo-rumen content. This approach is not common in the literature and is used here to study the effects of silage (by comparison to hay) and of quality of silage preservation.

\section{MATERIAL AND METHODS}

\section{Animals and feeds}

In July 1990, a cocksfoot meadow in the second cycle of vegetation was mown to prepare three differently preserved forages: a direct-cut silage, without additive and harvested with a precision chop forage harvester (WAS); the same forage, but treated with $4.4 \mathrm{I}$ of formic acid (FAS); and hay $(H)$, field cured in favourable conditions.

The 3 forages were distributed from September to December to six 4-year-old castrated Texel sheep (initial live weight $60 \pm 3 \mathrm{~kg}$ ) fitted with a rumen cannula $75 \mathrm{~mm}$ in diameter.

The required amounts of silage were removed from the silo twice a week and stored at $+4{ }^{\circ} \mathrm{C}$. Throughout the experimental period the animals were maintained with lights off from $21.00 \mathrm{~h}$ to $07.00 \mathrm{~h}$ and with lights on for the rest of the time, to achieve a constant photoperiod. The animals were fed ad libitum (10\% refusal) with a single feeding a day at $8.30 \mathrm{~h}$. They had free access to the forages, water and salt licks.

\section{Experimental design}

The experimental design was a replicated $3 \times 3$ Latin square, using 2 sheep simultaneously per treatment. Each of the 3 periods lasted 5 weeks, divided as follows: 1 week of adaptation to the diet; 1 week of adaptation to the metabolism crates; 1 week of measuring digestibility, the kinetics of intake during the day and eating and ruminating behavior; 2 weeks with the animals still in metabolism crates, during which 4 complete emptyings of the reticulo-rumen were performed.

\section{Measurements}

The digestibility of the 3 forages in vivo was determined by collecting the total faecal production. Concomitantly, but in 3 different sheep receiving a good quality lucerne hay, the kinetics of the DM degradation of the 3 forages was studied in situ (Demarquilly and Chenost, 1969) at incubation times in the rumen of $0,4,8,16$, 24,48 and $72 \mathrm{~h}$. On removal from the rumen, the nylon bags ( 2 per incubation period and per sheep) were washed in cold water and placed in a pepsin solution for $48 \mathrm{~h}$.

Daily intake was calculated by measuring the difference between the amounts offered and refused. Mangers were placed on sensors fitted with strain gauges (Baumont et al, 1988) coupled to a computer so that the intake could be determined for each meal throughout the day without disturbing the animals. At the same time, eating and ruminating behaviour was observed according to the technique of Ruckebush (1963), as adapted by Baumont et al (1988). The pressure signals transmitted by a balloon filled with polyurethane foam were immediately read into the computer and analyzed with software developed by Brun et al (1984). Likewise, we recorded the motility of the reticulo-rumen by means of another balloon placed in the dorsal sac of the rumen and connected to a pressure transducer.

The total reticulo-rumen contents were withdrawn by hand at $8.30,10.30,15.30$ and $20.30 \mathrm{~h}$. Emptyings were made at intervals of at least 72 $h$, to allow digestion to retum to normal (Aitchison, 1985). For a given time, all animals were treated together. All these contents were weighed and sampled after homogenization to determine DM content ( $48 \mathrm{~h}$ at $80^{\circ} \mathrm{C}$ ), dry samples being kept for analysis, particle size, and to measure $\mathrm{pH}, \mathrm{VFA}$ (volatile fatty acids) and ammonia content, osmotic pressure and viscosity in the fluid. 
The disappearance rate of digesta was calculated in $\mathrm{g} / \mathrm{h}$ between 2 different times according to the formula: disappearance rate $=$ (initial content + amount ingested-final content) / duration.

\section{Chemical analyses}

During the measurement periods, a representative sample of silage and hay was taken at each feeding. The DM content of the samples was determined after drying at $80^{\circ} \mathrm{C}$ for $48 \mathrm{~h}$ and corrected for silage according to the recommendations of Dulphy et al (1975b), which take into account losses in volatile DM during oven drying. Crude protein content was determined in undried silage. The other analyses were made on samples after drying: ash was determined after incineration for $6 \mathrm{~h}$ at $550^{\circ} \mathrm{C}$, nitrogen by the method of Kjeldahl and total cell walls (NDF) according to Goering and Van Soest (1970).

The fermentation characteristics of the silages $(\mathrm{pH}, \mathrm{VFA}$, lactic acids, ammonia and soluble nitrogen) were determined in fluid expressed under pressure. Ammonia was immediately assayed according to the method of Conway (1957) and soluble nitrogen by that of Kjeldahl. The fluid sample for lactic acid assay was conserved frozen without additives and then analyzed by the method of Noll (1974). Another fluid sample was treated with orthophosphoric acid and stabilizing agent and frozen for VFA and alcohol assay (Jouany, 1981).

The characteristics of the reticulo-rumen contents were determined either overall (particle size) or on dry matter, or on fluid filtered through a $1-\mathrm{mm}$ mesh grid. Particle size was estimated after sieve separation in a liquid flow according to the method of Grenet (1970). The dry samples were ground $(0.8 \mathrm{~mm}$ grid) for estimation of the plant cell walls. In the fluid, VFA were analyzed according to the method of Jouany (1981) and ammonia by the method of Berthelot (fluid treated with $\mathrm{NaCl}$ and frozen). In the fluid, we also estimated osmotic pressure by cryometry, and viscosity from the flow time into a capillary tube (Dardillat and Baumont, 1992).

\section{Statistical analysis}

Statistical significance of the feed intake, eating and ruminating activities, motility of reticulorumen, extent of rumen fill, characteristics of the reticulo-rumen contents and some parameters of the digestion were tested using an analysis of variance with the effects of animal (5 DF), type of forage (2 DF) and period (2 DF) and with 8 $D F$ in the error term. The calculations were performed using the general linear model procedure of the Statistical Analysis System Institute (SAS, 1985).

\section{RESULTS}

\section{Chemical composition and digestibility of forages}

Table I shows the chemical composition of the 3 forages. The 2 silages were very wet. Overall, ash content was rather high and crude protein rather low for regrowths (Andrieu et al, 1988). In vivo digestibility of the silage with additives was slightly higher than that of the other 2 forages (+ 3.6 points for OM). The kinetics of digestion in sacco, in the rumen, were almost identical: the variables $A$ and $B$, calculated from the model of Ørskov and Mac Donald (1979) were comparable for the 2 silages. In contrast, the value of $B$ was lower for hay. The degradation rate $C$ was highest for silage with FAS and lowest for WAS.

Table II shows the fermentation characteristics for the 2 silages. The silage without additive contained practically no lactic acid but a high level of VFA, including $9 \mathrm{~g}$ of propionic lactic acid, $5.5 \mathrm{~g}$ of valeric acid and $10.5 \mathrm{~g}$ of hexanoic acid per $\mathrm{kg} \mathrm{DM}$.

\section{Intake, eating behaviour and motility of the reticulo-rumen}

Silage intake was considerably smaller than hay intake (table III). Although the intake of silage with additive was markedly higher $(+18 \%)$ than that of silage without, there was no significant difference between the 2 . In relation to the metabolic 
Table I. Characteristics of forages studied.

Silage without additive WAS

157

128

125

601

$64.3^{\mathrm{b}}$

$66.6^{\mathrm{b}}$

NDF

Digestibility in sacco

(parameters of the adjusted curve)

(dry matter)
$A$
$A+B$
C

\section{Chemical composition}

Ash

Total cell walls (NDF)
31.3

76.3

0.034
Sillage with additive

FAS
Hay

H
170

117

119

594

$67.9^{\mathrm{a}}$

$69.3^{\mathrm{a}}$
880

112

103

658

NB : For different treatment results followed by different letters are significantly different.

Table II. Fermentation characteristics of the silages.
The daily time spent eating hay was longer than with the silages $(+25 \%)$ but there was less difference between ingestion rates $(+12 \%$ between WAS and $\mathrm{H}$, which is not significant).

Intake during the main meal was significantly higher for hay than for the silages, + 22 and $44 \%$, compared to FAS and WAS respectively. The rates of intake were comparable, although slightly lower for hay, so that the duration of the main meals differed significantly according to the treatment. In contrast, these rates were much higher for silages at the beginning of the main meal. For hay, they were regular throughout the meal.

There was no significant difference between the number of secondary meals a day. weight of the sheep, the amounts ingested were $48.8,57.6$ and $66.2 \mathrm{~g}$ of $\mathrm{DM} / \mathrm{kg}$ Wo.75 respectively for WAS, FAS and $H$.
30.0

77.8

68.5

0.039
$\mathrm{pH}$

Soluble N \% total N

Lactic acid

Acetic acid

Butyric acid

Total VFA

Total alcohol

92.5

3.5

41.5

4.5 
Table III. Intake, eating and ruminating behaviour of animals.

\begin{tabular}{|c|c|c|c|c|}
\hline Silage & $\begin{array}{l}\text { without additive } \\
\text { WAS }\end{array}$ & $\begin{array}{l}\text { Silage with additive } \\
\text { FAS }\end{array}$ & $\stackrel{\text { Hay }}{H}$ & $R S D^{*}$ \\
\hline \multicolumn{5}{|l|}{ Day } \\
\hline DM intake $(\mathrm{g})$ & $1054^{b}$ & $1241^{b}$ & $1469^{a}$ & 142 \\
\hline Duration (min) & $303^{b}$ & $325^{\mathrm{ab}}$ & $393^{a}$ & 57 \\
\hline Ingestion rate $(\mathrm{g} / \mathrm{min})$ & $3.50^{\mathrm{a}}$ & $3.85^{\mathrm{a}}$ & $3.92^{\mathrm{a}}$ & 0.4 \\
\hline \multicolumn{5}{|l|}{ Main meals } \\
\hline DM intake $(\mathrm{g})$ & $270^{b}$ & $317^{6}$ & $388^{a}$ & 38 \\
\hline Duration (min) & $58^{\mathrm{c}}$ & $72^{b}$ & $93^{a}$ & 9 \\
\hline \multicolumn{5}{|l|}{ Ingestion rate $(\mathrm{g} / \mathrm{min})$} \\
\hline Total meal & $4.76^{a}$ & $4.56^{\mathrm{a}}$ & $4.16^{a}$ & 0.60 \\
\hline First $15 \mathrm{~min}$ & $6.80^{\mathrm{a}}$ & $5.93^{a}$ & $4.07^{b}$ & 0.73 \\
\hline First $30 \mathrm{~min}$ & $5.80^{\mathrm{a}}$ & $6.07^{a}$ & $4.50^{\mathrm{b}}$ & 0.68 \\
\hline Number of secondary meals & $10.2^{\mathrm{a}}$ & $10.5^{\mathrm{a}}$ & $9.5^{\mathrm{a}}$ & 2.2 \\
\hline \multicolumn{5}{|l|}{ Rumination } \\
\hline Daily duration (min) & $417^{c}$ & $457^{b}$ & $535^{a}$ & 28 \\
\hline Number of cycles & $506^{\mathrm{b}}$ & $569^{a}$ & $612^{a}$ & 37 \\
\hline Duration of cycles (sec) & $50^{\mathrm{ab}}$ & $48^{b}$ & $52^{\mathrm{a}}$ & 2 \\
\hline \multicolumn{5}{|l|}{ Time between distribution } \\
\hline and beginning of rumination (min) & $182^{\mathrm{a}}$ & $161^{\mathrm{a}}$ & $138^{\mathrm{a}}$ & 37 \\
\hline \multicolumn{2}{|l|}{ Time between end of main meal } & $89^{a b}$ & $45^{b}$ & 41 \\
\hline \multicolumn{5}{|l|}{ Chewing } \\
\hline Daily duration (min) & $720^{b}$ & $782^{b}$ & $927^{a}$ & 76 \\
\hline Efficiency $(g / \mathrm{min})$ & $1.47^{b}$ & $1.59^{a}$ & $1.60^{\mathrm{a}}$ & 0.08 \\
\hline
\end{tabular}

* RSD: residual standard deviation of the analysis of variance $(8 \mathrm{ddl})$.

The daily duration of rumination varied significantly, with a difference of $28 \%$ between WAS and $\mathrm{H}$.

Figure 1 shows the daily pattern of eating and rumination at $1 \mathrm{~h}$ intervals. The results confirm the importance of the main meal for hay intake. They also show a significant recovery in hay intake between 16 and $19.00 \mathrm{~h}$. There was a similar recovery for FAS only at $18.00 \mathrm{~h}$, but not for WAS.

Although forage was distributed only once, there were 2 peaks of rumination in the day (fig 1). With hay, the latency time was shorter and rumination always began more quickly (table III). The rumination cycles had an average duration of $50 \mathrm{~s}$ and although the difference in times between FAS and $H$ was significant, the values measured were very similar.

The time spent chewing daily was comparable on the 2 silages (on average 750 min) but significantly higher (23\%) with hay. In contrast, chewing efficiency was the same for FAS and $\mathrm{H}$ and slightly lower 

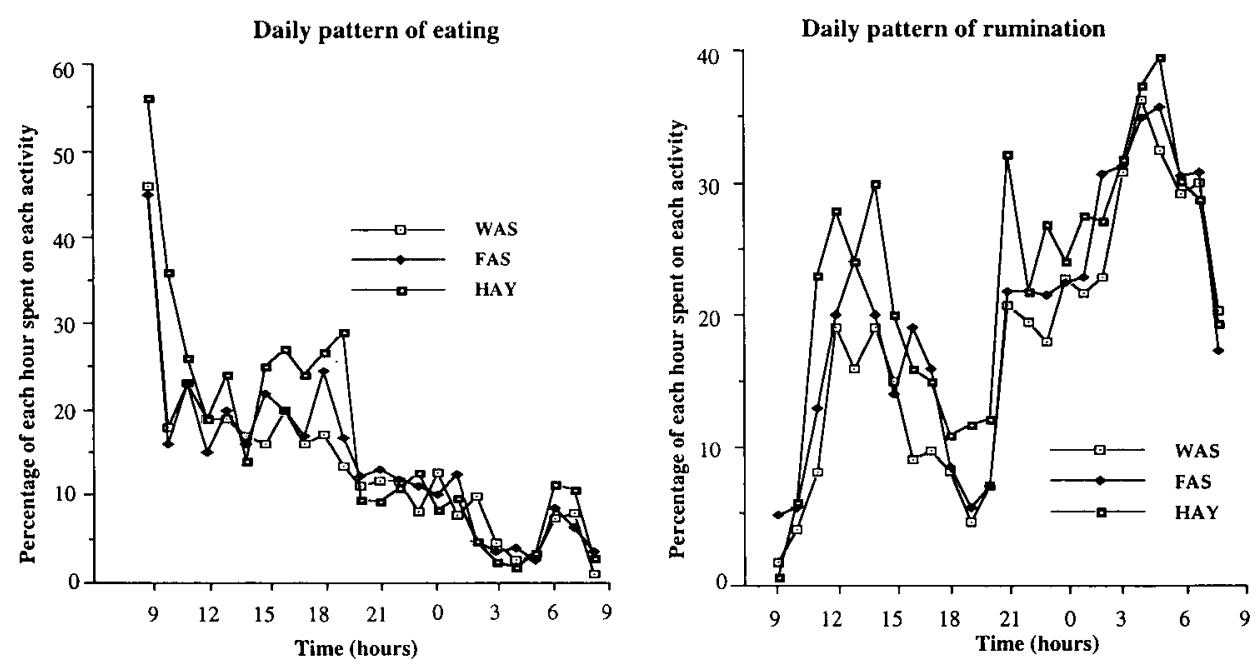

Fig 1. Evolution of feeding behaviour during the day.

$(-8 \%)$ for WAS. However, if we report the time spent ruminating per unit DM digesta present in the reticulo-rumen we obtain the same figure for the 3 forages: $0.36 \mathrm{~min} / \mathrm{g}$ DM digesta.

Table IV shows the number of contractions of the reticulo-rumen per min. Over- all, this number was higher for FAS and lower for hay. If the numbers are offset by taking account of the real duration of each activity, we find 1741,1830 and 1752 of type A contractions per day for WAS, FAS and $H$ respectively. The values for the total contractions were 2893,3181 and 3052.

Table IV. Number of contractions per min of the reticulo-rumen according to the type of activity.

$$
\begin{array}{cccc}
\text { Silage without additive } & \text { Silage with additive } \\
\text { WAS } & \text { Hay } & H & R S D
\end{array}
$$

Type A contractions

Main meals

Small meals

Rest

Rumination

Type $A+B$ contractions

Main meals

Small meals

Rest

Rumination

$1.70^{\mathrm{a}}$
$1.51^{\mathrm{ab}}$
$1.04^{\mathrm{ab}}$
$1.23^{\mathrm{a}}$

$3.40^{\mathrm{a}}$

$2.80^{\mathrm{ab}}$

$1.66^{\mathrm{b}}$

$1.87^{\mathrm{b}}$

$1.78^{a}$
$1.57^{a}$
$1.07^{a}$
$1.28^{a}$

$3.56^{\mathrm{a}}$

$2.99^{\mathrm{a}}$

$1.83^{\mathrm{a}}$

$2.02^{a}$ $1.49^{b}$

$1.45^{\mathrm{b}}$

$1.01^{\mathrm{b}}$

$1.23^{a}$

$2.93^{b}$

$2.74^{\mathrm{b}}$

$1.74^{\mathrm{ab}}$

$1.96^{\mathrm{ab}}$
0.06

0.05

0.04

0.06 


\section{Extent of reticulo-rumen fill and physical characteristics of the contents}

Table $V$ shows the amounts of fresh matter, DM and total cell wall contents. There was no significant difference between the 2 silages: an average of $10266 \mathrm{~g}$ fresh matter for WAS and $10668 \mathrm{~g}$ for FAS $(+4 \%)$ and $1153 \mathrm{~g} \mathrm{DM}$ for WAS and $1224 \mathrm{~g}$ for FAS $(+6 \%)$. The values for hay were much higher, with significant differences at 10.30 and $15.30 \mathrm{~h}$ compared to silages (on average, $11988 \mathrm{~g}$ fresh matter and $1479 \mathrm{~g} \mathrm{DM}$ over the day). On the basis of total cell wall contents, the reticulo-rumen contents were higher with hay (on average, $994 \mathrm{~g}$ vs 775 and $814 \mathrm{~g}$ with WAS and FAS).

The DM level of the contents was highest with hay, but overall there was little difference between the forages (table VI). The levels were low before the morning meal (107 g/fresh $\mathrm{kg}$ ) and remained steady at 119 and $123 \mathrm{~g}$ after the main meal and in the evening respectively (fig 2 ). The cell wall levels of the contents were very similar with only slight variations during the day: an average maximum of 677 at $15.30 \mathrm{~h}$ and a minimum of $656 \mathrm{~g} / \mathrm{kg} \mathrm{DM}$ at $20.30 \mathrm{~h}$.

There was little difference between the 2 silages in the size of ruminal particles (table VI), except for a slight inversion between the small particles $(0.05-1 \mathrm{~mm})$ and the soluble compounds with the latter being a little higher with the well preserved silage. In contrast there were fewer large particles with hay $(-9 \%$ left on the $8 \mathrm{~mm}$ mesh sieve) but more medium-sized particles $(+70 \%$ on mesh between $1-8 \mathrm{~mm})$ and hence more particles $\geq 1 \mathrm{~mm}$ (fig 2). When observed with the naked eye, these particles generally seemed to be larger for hay than for the silages, but no precise measurement was made.

Table $\mathrm{V}$. Influence of the nature of the forage on reticulo-rumen fill.

\begin{tabular}{|c|c|c|c|c|}
\hline $\operatorname{lng}$ & $\begin{array}{l}\text { Silage without additive } \\
\text { WAS }\end{array}$ & $\begin{array}{l}\text { Sillage with additive } \\
\text { FAS }\end{array}$ & $\begin{array}{l}\text { Hay } \\
H\end{array}$ & $R S D$ \\
\hline \multicolumn{5}{|l|}{ Fresh matter } \\
\hline $8.30 \mathrm{~h}$ & $8689^{a}$ & $9266^{a}$ & $9930^{a}$ & 1151 \\
\hline $10.30 \mathrm{~h}$ & $10941^{\mathrm{ab}}$ & $10773^{b}$ & $12298^{a}$ & 1032 \\
\hline $15.30 h$ & $10561^{b}$ & $10931^{b}$ & $12854^{a}$ & 1296 \\
\hline $20.30 \mathrm{~h}$ & $10874^{a}$ & $11702^{a}$ & $12870^{a}$ & 1515 \\
\hline \multicolumn{5}{|l|}{ Dry matter } \\
\hline $8.30 \mathrm{~h}$ & $943^{a}$ & $993^{a}$ & $1088^{a}$ & 147 \\
\hline $10.30 \mathrm{~h}$ & $1269^{b}$ & $1267^{b}$ & $1529^{a}$ & 96 \\
\hline $15.30 \mathrm{~h}$ & $1123^{b}$ & $1220^{b}$ & $1602^{a}$ & 171 \\
\hline $20.30 \mathrm{~h}$ & $1279^{b}$ & $1416^{a b}$ & $1697^{a}$ & 256 \\
\hline \multicolumn{5}{|l|}{ Total cell walls } \\
\hline $8.30 \mathrm{~h}$ & $639 a$ & $663^{a}$ & $722^{a}$ & 101 \\
\hline $10.30 \mathrm{~h}$ & $856^{b}$ & $851^{b}$ & $1037^{a}$ & 70 \\
\hline $15.30 \mathrm{~h}$ & $760^{b}$ & $821^{b}$ & $1095^{a}$ & 122 \\
\hline $20.30 \mathrm{~h}$ & $846^{b}$ & $923^{a b}$ & $1120^{a}$ & 181 \\
\hline
\end{tabular}


Table VI. Mean characteristics of reticulo-rumen contents.

\begin{tabular}{lcccc}
\hline & $\begin{array}{c}\text { Silage without additive } \\
\text { WAS }\end{array}$ & $\begin{array}{c}\text { Silage with additive } \\
\text { FAS }\end{array}$ & $\begin{array}{c}\text { Hay } \\
H\end{array}$ & $R S D$ \\
& & & & \\
\hline & $111^{\mathrm{b}}$ & $113^{\mathrm{b}}$ & $122^{\mathrm{a}}$ & 9 \\
$\mathrm{DM}$ content g/kg & $672^{\mathrm{a}}$ & $665^{\mathrm{b}}$ & $670^{\mathrm{ab}}$ & 10.7 \\
$\mathrm{NDF}$ content g/kg DM & $6.60^{\mathrm{a}}$ & $6.50^{\mathrm{b}}$ & $6.37^{\mathrm{c}}$ & 0.16 \\
$\mathrm{pH}$ & $100^{\mathrm{b}}$ & $138^{\mathrm{a}}$ & $99^{\mathrm{b}}$ & 34 \\
$\mathrm{~N}-\mathrm{NH}_{3} \mathrm{mg} / 1$ & $92^{\mathrm{b}}$ & $95^{\mathrm{b}}$ & $106^{\mathrm{a}}$ & 9 \\
VFA mmol/ & $68.6^{\mathrm{b}}$ & $70.2^{\mathrm{a}}$ & $69.4^{\mathrm{ab}}$ & 2.2 \\
Acetic acid (\%) & $16.6^{\mathrm{c}}$ & $17.9^{\mathrm{b}}$ & $18.8^{\mathrm{a}}$ & 1.2 \\
Propionic acid (\%) & $11.5^{\mathrm{a}}$ & $8.8^{\mathrm{b}}$ & $9.6^{\mathrm{b}}$ & 1.6 \\
Butyric acid (\%) & $2.8^{\mathrm{a}}$ & $2.7^{\mathrm{a}}$ & $2.0^{\mathrm{b}}$ & 0.5 \\
Valerianic acid (\%) & $0.6^{\mathrm{a}}$ & $0.4^{\mathrm{b}}$ & $0.3^{\mathrm{c}}$ & 0.2 \\
Caproic acid (\%) & & & & \\
Particles retained on sieve (\%) & $213^{\mathrm{a}}$ & $215^{\mathrm{a}}$ & $194^{\mathrm{a}}$ & 42 \\
8 mm mesh & $82^{\mathrm{b}}$ & $86^{\mathrm{b}}$ & $143^{\mathrm{a}}$ & 23 \\
Between 1-8 mm mesh & $360^{\mathrm{a}}$ & $336^{\mathrm{b}}$ & $330^{\mathrm{b}}$ & 35 \\
Between 0.05-1 mm mesh & $345^{\mathrm{b}}$ & $362^{\mathrm{a}}$ & $334^{\mathrm{b}}$ & 26 \\
$<0.05 \mathrm{~mm}$ & & & & \\
$\quad$ (g/kg DM) & $264^{\mathrm{b}}$ & $261^{\mathrm{b}}$ & $281^{\mathrm{a}}$ & 9 \\
Osmotic pressure (mOsm/ml) & $1.07^{\mathrm{b}}$ & $1.01^{\mathrm{b}}$ & $1.26^{\mathrm{a}}$ & 0.18 \\
Viscosity (m.Pa/s) & & & & \\
\hline
\end{tabular}

The viscosity of the centrifuged rumen juice (fig 2) was practically the same for the 2 silages but a little higher $(+21 \%)$ for hay. On average, viscosity went from 1.20 before the meal to 1.08 afterwards and then to 1.06 and 1.12 at the subsequent emptyings. Likewise, the osmotic pressure of the rumen fluid (fig 2) was similar for the 2 silages but higher $(+7 \%)$ for hay.

\section{Chemical characteristics of the reticulo-rumen contents}

There was a significant difference in $\mathrm{pH}$ between the forages, and the level was lower for hay than for silages (table VI). On average, $\mathrm{pH}$ decreased regularly from 8.30 $h$ (6.71) to $20.30 \mathrm{~h}$ (6.29) (fig 3). Ammonia contents were the same for WAS and $H$ but higher for FAS. At $8.30 \mathrm{~h}$, the level was
$132 \mathrm{mg} / \mathrm{l}$ and at $10.30 \mathrm{~h} 137$, after which it decreased. The most clear-cut effect of the main meal (an increase in ammonia level of $47 \mathrm{mg} / \mathrm{l}$ in $2 \mathrm{~h}$ ) was observed with the WAS (fig 3).

VFA contents were about the same for the 2 silages and slightly higher for hay. The levels increased gradually throughout the day, from $84 \mathrm{mmol}$ at $8.30 \mathrm{~h}$ to 109 $\mathrm{mmol}$ at $20.30 \mathrm{~h}$ (fig 3 ). Overall, the proportions of acetic and propionic acid were lowest with WAS. In contrast, it was this silage that had the highest amounts of butyric, valeric and caproic acid. The proportions of valeric and caproic acid were lowest with hay. The most notable modifications were observed with WAS after the main meal, at which time the proportions of acetic, propionic, butyric, valeric and caproic acids reached levels of $65.5,15.3$, $13.7,3.5$ and $0.8 \%$ respectively. 

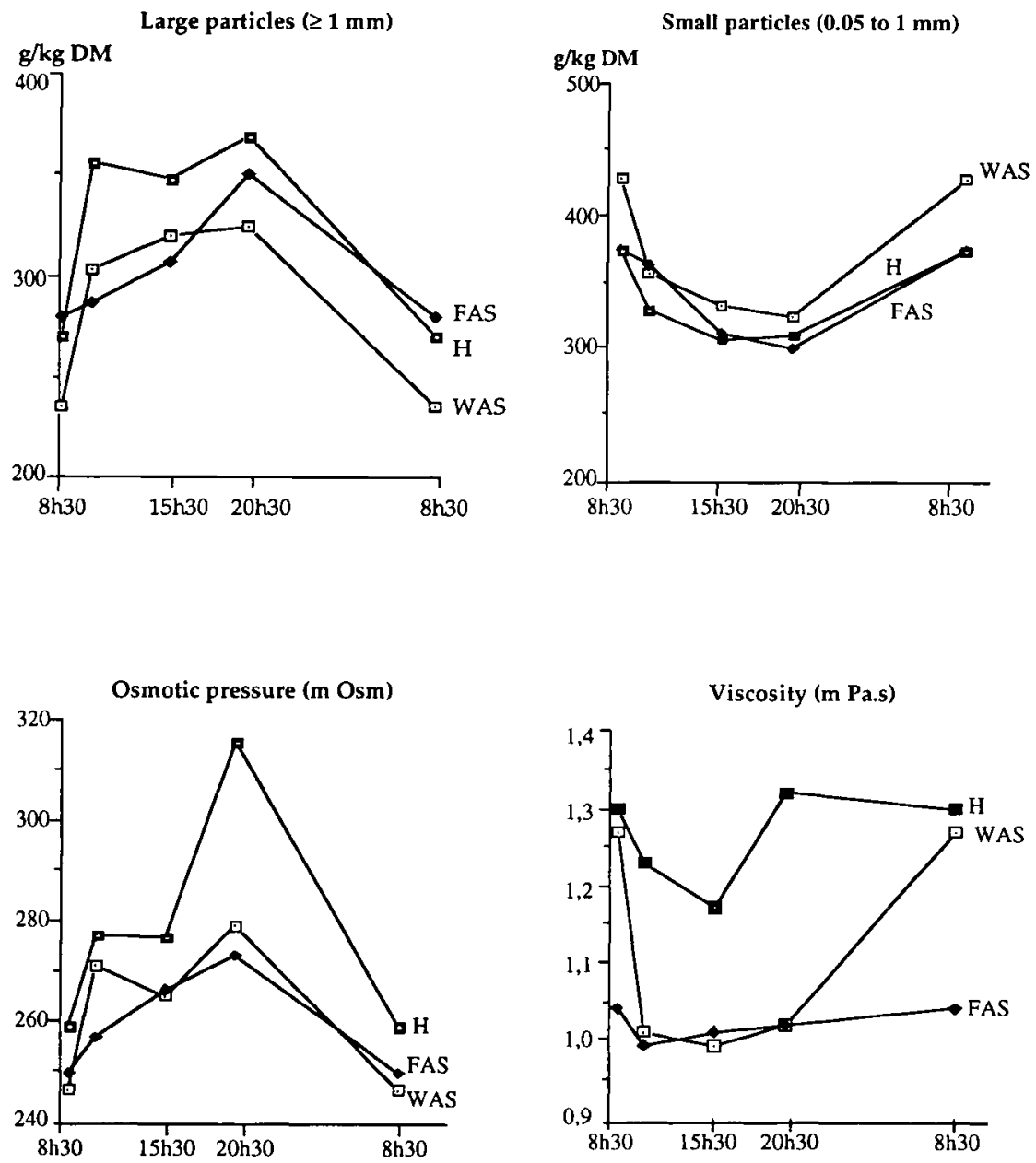

Fig 2. Evolution of the characteristics of the reticulo-rumen contents during the day (particles, osmotic pressure and viscosity).

\section{Rate of disappearance of digesta}

During the day there was no great difference in the rates of DM disappearance between the 3 forages (average of $48 \mathrm{~g} / \mathrm{h}$ ) but a marked increase at night for hay (table VII). The disappearance rates of the plant cell walls were also very similar ex- cept again for an increase with hay during the night. The DM turnover rate of the contents during the nycthemeral cycle was therefore the same for FAS and $\mathrm{H}$ and lower, but not significantly for WAS. The variations in the cell wall turnover rates, although slightly greater, were still not significant. 

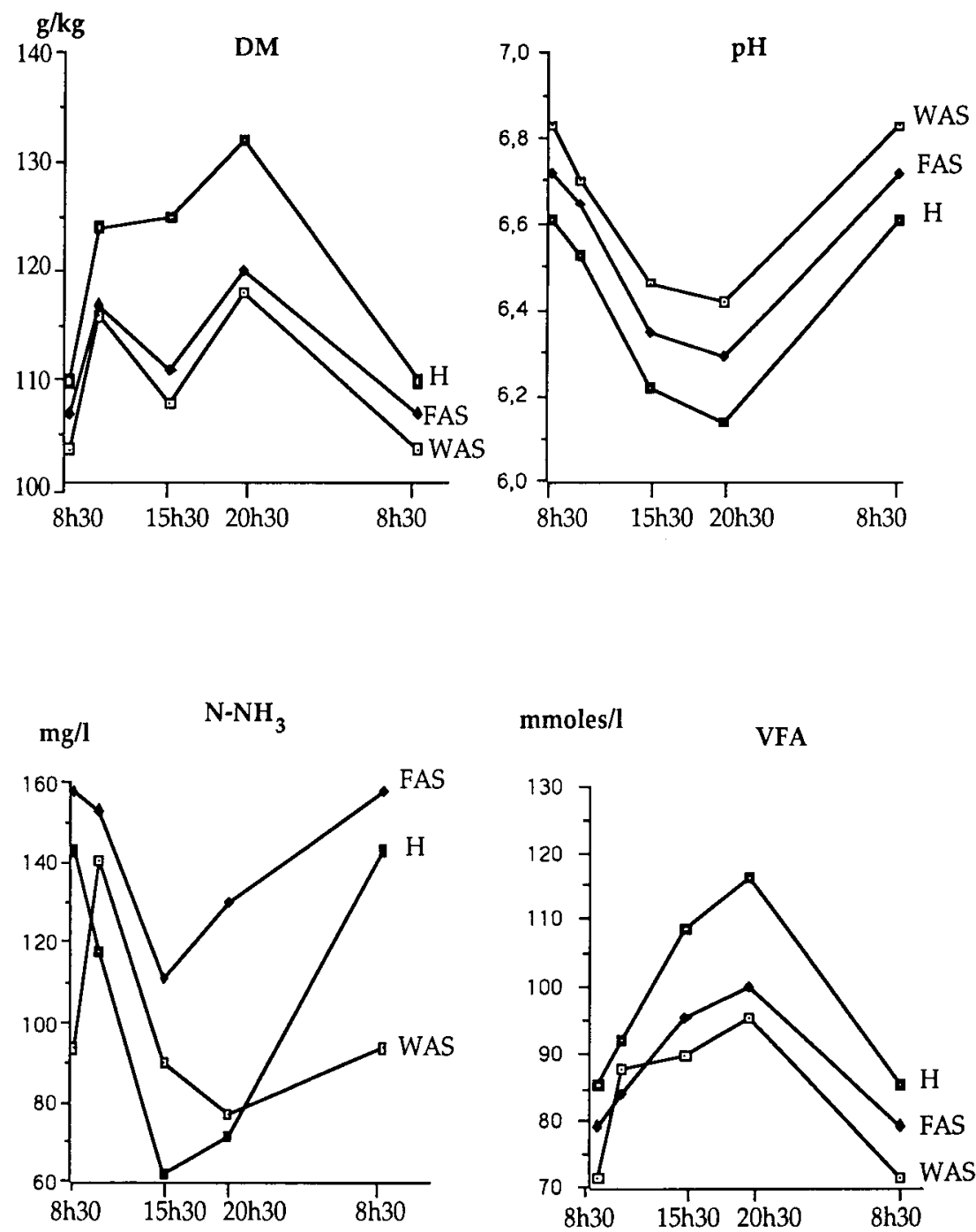

mmoles/l

VFA

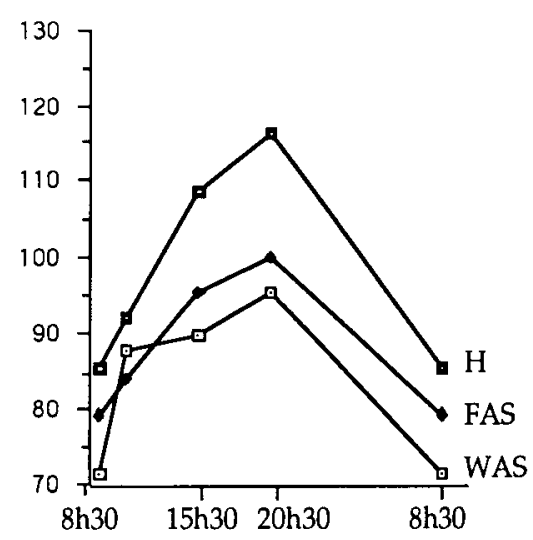

Fig 3. Evolution of the characteristics of the reticulo-rumen contents during the day (dry matter, $\mathrm{pH}$, $\mathrm{N}-\mathrm{NH}_{3}$ and volatile fatty acids).

\section{DISCUSSION}

The green forage from which the silages and hay were prepared was rich in water and probably poor in soluble carbohy- drates (Jarrige, 1981). As a result, the silage with additive was of mediocre quality and that without was very poorly preserved. Hence, in contrast to what is usually observed (Dulphy and Demarquilly, 1991), 
Table VII. Rate of disappearance of reticulo-rumen contents and turnover rate.

\begin{tabular}{|c|c|c|c|c|}
\hline & $\begin{array}{c}\text { Silage without additive } \\
\text { WAS }\end{array}$ & $\begin{array}{l}\text { Silage with additive } \\
\text { FAS }\end{array}$ & $\begin{array}{l}\text { Hay } \\
H\end{array}$ & $R S D$ \\
\hline \multicolumn{5}{|l|}{$\begin{array}{l}\text { DM disappearance rate } \\
(\mathrm{g} / \mathrm{h})\end{array}$} \\
\hline Day $(8.30 h-20.30 h)$ & $44.8^{\mathrm{a}}$ & $49.9^{a}$ & $48.8^{a}$ & 19.2 \\
\hline Night $(20.30 h-8.30 h)$ & $43.1^{\mathrm{b}}$ & $53.5^{\mathrm{ab}}$ & $73.6^{\mathrm{a}}$ & 19.2 \\
\hline \multicolumn{5}{|c|}{$\begin{array}{l}\text { Disappearance rate of plant cell walls } \\
(\mathrm{g} / \mathrm{h})\end{array}$} \\
\hline Day & $28.9^{a}$ & $32.5^{a}$ & $31.1^{\mathrm{a}}$ & 11.6 \\
\hline Night & $26.8^{b}$ & $33.4^{\mathrm{ab}}$ & $48.0^{\mathrm{a}}$ & 13.4 \\
\hline \multicolumn{5}{|l|}{ Turnover rate of contents } \\
\hline DM $(\% / h)$ & $3.89^{a}$ & $4.30^{\mathrm{a}}$ & $4.21^{a}$ & 0.63 \\
\hline NDF $(\% / h)$ & $3.48^{\mathrm{a}}$ & $3.85^{a}$ & $4.13^{a}$ & 0.58 \\
\hline
\end{tabular}

the intake of the silages was far lower than that of the hay. Likewise, the difference between the 2 silages themselves was greater than the standard dissimilarity (Dulphy and Michalet-Doreau, 1981). The difference corresponds however to that predicted by the equations given by these authors, in which the intake of the silage is in relation to the $\mathrm{pH}$ or the proportion of ammonia nitrogen. Finally, in comparison with the tables of Andrieu et al (1988), we obtained high, normal and low intake respectively for $\mathrm{H}$, FAS and WAS.

Differences in intake were observed from the main meal. With the WAS, the sheeps' appetite was quickly satisfied, as observed in a previous study (Dulphy, 1985) and in agreement with the findings of Gill et al (1988) in young cattle. However, contrary to what has often been reported (Dulphy et al, 1975a; Martin Clancy et al, 1977; Dulphy et al, 1984), the animals did not compensate for rapid satiety by increasing the number of their meals.

Yet the number of meals taken with the silage diets was not so different from that usually reported (Dulphy et al, 1984). With hay it was higher (Dulphy, 1972; Dulphy et al, 1975a), perhaps because there was just 1 feeding per day. The same increase in the number of meals with a hay diet has been observed elsewhere (Dulphy et al, 1988). These findings therefore suggest that the effects of the factors limiting intake of the 2 silages were persistent throughout the diurnal cycle, since there was a lower intake at each small meal.

There are several factors involved in the regulation of silage intake: oral (taste, odour, prehensibility; of Buchanan-Smith, 1990), digestive (rate of digestion, functioning of the reticulo-rumen; $c f$ Martin Clancy et al, 1977; Sissons et al, 1986) and metabolic, via mechanisms that maintain the homeostasis of the animals.

One approach to organoleptic problems is to study the rate of ingestion, a variable which often sharply discriminates between the different types of silage. The rate decreases when the silage particles are longer (Dulphy and Demarquilly, 1973) and if there is no additive (Dulphy et al, 1984). 
Strangely, in the present trial, this rate was not affected by the silage conservation method. Moreover, the silages were injected during the main meal at a faster rate than the hay. Problems of palatability did not therefore seem to limit intake of the 2 silages studied. In this respect, BuchananSmith (1990) stresses the negative role of acetic acid, of which there were similarly moderate amounts in our 2 si-lages. In agreement with the findings of the same author, we observed no effet of ammonia or of butyric, valeric and caproic acids.

Three aspects of digestion can be studied; the efficiency of rumination, the rate of digestion and reticulo-rumen fill. The efficiency of rumination was a little lower with the silage containing no additive. The reasons for this are difficult to determine since there was little difference between the digestion rates and digestibilities of the 3 forages. The digestion rate may have been a little slower for WAS. However, these observations are not sufficient to explain the differences in intake. Elsewhere, per unit of rumen digesta, the efficiency of rumination was exactly the same for the 3 treatments. For the same silage, the latency time between the end of the main meal and the beginning of rumination was much longer. The intake of poorly preserved silage therefore tended to 'disturb' rumination more than that of silage with additive. However, this may simply have been due to the fact that rumen fill was lower with silage than with hay.

Our findings showed that reticulo-rumen fill was greater for hay than for silages, and are consistent with previous reports (Campling, 1966; Thiago and Gill, 1986; Waldo et al, 1966), confirming that the animals' rumen capacity, at least in these trials, was not a factor that limited silage intake. In ratio to the metabolic weight of the animals, the average amounts of fresh content reached highest levels of 510,540 and
$600 \mathrm{~g}$ per $\mathrm{kg} \mathrm{BW} 0.75$ respectively for the 3 forages. These values were high compared to those of several other reports (Dulphy et al, 1975a; Baumont et al, 1988; Dulphy et al, 1988) but comparable (595 g) for hay to the results of Baumont et al (1990). The fact that the forage was well or poorly preserved had little effect on rumen fill, in contrast to results of a trial performed by Dulphy et al (1975a).

The fall in silage intake therefore resulted in a decrease in the reticulo-rumen contents. For WAS, a lower turnover rate of the contents was also observed. However, there is no evidence that the intake of the 2 silages studied was limited by a decrease in the animals' digestive capacity.

Given the composition of the grass silages, 2 series of compounds may be involved in metabolic changes: acids, or the products of the decomposition of nitrogen matter (Miettinen et al, 1991), or both. Because of this, it is often difficult to identify the compounds involved and to determine where and how their effects are achieved.

Certain end-products of the fermentation of finaly chopped silages quickly satisfy the animal's appetite before the rumen is filled. Several compounds may play a role: VFA, nitrogen compounds and probably lactic acid also (Morgan and L'Estrange, 1977; Thomas et al, 1980). Since the phenomenon occurs with all silages, the acids must be involved. Satiety is even more quickly reached if the silage is poorly conserved, so compounds from the degradation of nitrogen have an effect. When they are given well-preserved silage, animals may offset early satisfaction of hunger by eating more often, and in sizeable amounts, so that they ingest as much silage as hay (Dulphy and Demarquilly, 1991). This did not happen in our trial because the silage with additive was of mediocre quality. With poorly conserved silages, which hence are rich in VFA or am- 
monia or in both, 2 sets of mechanisms may come into play simultaneously. The time spent eating and the amount ingested per meal may decrease, as in our experiment, in proportion to the poor state of conservation of the silage. The receptor areas are probably situated in the stomachs. The animals' lack of appetite, as evidenced by a slow intake rate, can also shorten the duration of meals or reduce the amount ingested for the same time spent eating (Dulphy et al, 1984; Buchanan-Smith and Philipp, 1986). The number of meals themselves may also decrease. While this decrease is only slight with well chopped silages, it is clear-cut in those with long particles (Dulphy and Demarquilly, 1973). The limiting effects of chemical or physical factors last longer in the rumen in this case, or eating may be delayed by the animals' lack of motivation. The latter possibility is supported by the findings of Gatel (1984) and Baumont et al (1990), who observed that the unpalatability of diets could be largely responsible for short-term satiety. In the present trial, however, this factor did not seem to be important.

An interesting question is how these end-products of the silage limit intake. We can suggest a direct action on chemical receptors, but it is also possible that silage feeding may elicit a signal which does not permit the rumen to fill to the same level as with hay.

In conclusion, organoleptic factors are not involved in the low intake of our silages. In the same way, the digestive capacity of the animals, their ability to reduce particles, the rate of digestion of the silages and their flow out of the rumen do not limit intake. The observation of the feeding activities of sheep indicates a strong action of the fermentation products leading to rapid satiety. This behavioral approach is very original and must be used in a more systematic way in the fu- ture to obtain a better understanding of the mechanisms modifying intake of the conserved forages.

\section{ACKNOWLEDGMENT}

We thank $\mathrm{J}$ Lefaivre for animal surgery.

\section{REFERENCES}

Aitchison EM (1985) A study of the removal of fibre from the rumen and voluntary intake of sheep eating hay diets. PhD thesis, University of Reading

Andrieu J, Demarquilly C, Sauvant D (1988) Tables de la valeur nutritive des aliments. In : Alimentation des Bovins, Ovins et Caprins. INRA, Paris

Baumont R, Dulphy JP, Andrieu JP (1988) Comportement alimentaire et état de répletion du réticulo-rumen chez le mouton nourri à volonté de foin de prairie ou de luzerne, avec accès continu ou limité : incidences sur le contrôle physique de l'ingestion. Reprod Nutr Dev 28, 573-588

Baumont R, Seguier N, Dulphy JP (1990) Rumen fill, forage palatibility and alimentary behaviour in sheep. J Agric Sci (Camb) 115, 277-284

Brun JP, Prache S, Bechet G (1984) A portable device for eating behaviour studies. In: 5 th Meeting European Grazing Workshop (Armstrong R, Doney J, eds) Hill Farming Research Organisation, Midlothian

Buchanan-Smith JG (1990) An investigation into palatibility as a factor responsible for reduced intake of silage by sheep. Anim Prod 50, 253-260

Buchanan-Smith JG, Philipp LE (1986) Food intake in sheep following intraruminal infusion of extracts from lucerne silage with particular reference to organic acids and products of protein degradation. J Agric Sci (Camb) 106, 611-617

Campling RC (1966) The intake of hay and silage by cows. $J$ Br Grassland Soc 21, 41-49

Conway EJ (1957) Microdiffusion Analysis and Volumetric Error. Crosby, Lockwood, London, vol 8, $468 \mathrm{p}$ 
Dardillat C, Baumont R (1992) Physical characteristics of reticular content in the bovine and consequences on reticular outflow. Reprod Nutr Dev 32, 21-36

Demarquilly C (1973) Composition chimique, caractéristiques fermentaires, digestibilité et quantité ingérée des ensilages de fourrages : modifications par rapport au fourrage vert initial. Ann Zootech 22, 1-35

Demarquilly C, Andireu J, Weiss P (1981) L'ingestibilité des fourrages verts et des foins et sa prévision. In: Prévision de la Valeur Nutritive des Aliments des Ruminants. INRA, 155-167

Demarquilly C, Chenost M (1969) Étude de la digestion du fourrage dans le rumen par la méthode des sachets de nylon: liaison avec la valeur alimentaire. Ann Zootech 18, 419-436

Deswysen A, Vanbelle M, Focant M (1978) The effect of silage chop length on the voluntary intake and rumination behaviour of sheep. $J$ Br Grassland Soc 33, 107-115

Dulphy JP (1972) Influence du mode de conservation des fourrages de graminées sur la vitesse de leur digestion dans le rumen. Ann Zootech 21, 525-534

Dulphy JP (1985) Étude des quantités ingérées lors des grands repas chez des moutons recevant des fourrages ensilés. Ann Zootech $34,401-406$

Dulphy JP, Demarquilly C (1973) Influence de la machine de récolte et de la finesse de hachage sur la valeur alimentaire des ensilages. Ann Zootech 22, 199-217

Dulphy JP, Demarquilly C (1991) Digestibility and intake voluntary of conserved forage. $\mathrm{In}$ : Forage Conservation Towards 2000 (Pahlow G, Honig $H$, eds) Eur Grassland Fed, 140 . 160

Dulphy JP, Michalet-Doreau B (1981) Prévision de l'ingestibilité des ensilages d'herbe. Prévision de la valeur nitritive des aliments des ruminants. INRA, 169-187

Dulphy JP, Bechet G, Thomson E (1975a) Influence de la structure physique et de la qualité de conservation des ensilages de graminées sur leur ingestibilité. Ann Zootech 24, 81-94

Dulphy JP, Demarquilly C, Henry M (1975b) Perte de composés volatils lors de la détermination à l'étuve de la teneur en matière sèche des ensilages. Ann Zootech 24, 743-756
Dulphy JP, Michalet-Doreau B, Demarquilly C (1984) Étude comparée des quantités ingérées et du comportement alimentaire et mérycique d'ovins et de bovins recevant des ensilages d'herbe réalisés selon différentes techniques. Ann Zootech 33, 291-320

Dulphy JP, Eimeddah Y, Baumont R (1988) Influence du rythme de distribution sur les activités alimentaires et l'évolution journalière du contenu ruminal chez le mouton. Reprod Nutr Dév 28, 919-929

Gatel $F$ (1984) Signification de la satiété à court terme chez le mouton : influence de la qualité du fourrage et des stimuli associés à la prise de nourriture. Ann Zootech 33, 111-118

Gill M, Rook AJ, Thiago LRS (1988) Factors affecting the voluntary intake of roughages by the dairy cow. In: Nutrition and Lactation in the Dairy Cow (Garnsworthy PC, ed) Butterworths, London, 262-279

Goering HK, Van Soest PJ (1970) Forage Fiber Analyses. Agriculture Handbook 379. Agric Res Serv, US Dept Agric, $20 \mathrm{p}$

Grenet E (1970) Taille et structure des particules végétales au niveau du feuillet et des fèces chez des bovins. Ann Biol Anim Bioch Bioph 10, 643-657

Hutchinson KJ, Wilkins RJ (1971) The voluntary intake of silage by sheep. 2. The effects of acetate on silage intake. $J$ Agric Sci (Camb) $77,539-548$

Jarrige $R$ (1981) Les constituants glucidiques des fourrages : variations, digestibilité et dosage. In: Prévision de la Valeur Nutritive des Aliments des Ruminants. INRA, 13-40

Jouany JP (1981) Dosages des acides gras volatils et des alcools dans les ensilages par chromatographie en phase gazeuse. Bull Techn CRZV Theix INRA, 46, 63-66

Martin Clancy PJ, Wangsness PJ, Baumgardt BR (1977) Effect of silage extract on voluntary intake, rumen fluid constituents and rumen motility. J Dairy Sci 60 (4), 580-590

Miettinen H, Setälä J, Moisio T (1991) Estimation of the effect of silage quality on silage palatibility and intake in dairy cows. In: Forage Conservation Towards 2000 (Pahlow G, Honig H, eds) Eur Grassland Fed, 408409

Morgan DJ, L'Estrange JL (1977) Voluntary feed intake and metabolism of sheep when lactic 
acid is administered in the feed or intraruminally. J Br Grassland Soc 32, 217-224

Noll (1974) Methods of Enzymatic Analysis (Bergmeyer HU, ed) Academic Press, New York, vol 3, p 1475

Ørskov ER, Mac Donald I (1979) Estimation of protein degradability in the rumen from incubation measurements weighted according to rate of passage. J Agric Sci (Camb) 92, 499-503

Ruckebush $Y$ (1963) Recherches sur la régulation centrale du comportement alimentaire chez les ruminants. Thèse Doc Sci Nat Univ Lyon, 213 p

SAS Institute (1985) SAS Users' Guide. SAS Institute Inc, USA

Sissons JW, Gill M, Thiago LRS (1986) Effect of conservation method and frequency of feeding on forestomach motility. Proc Nutr SoC vol $45,96 \mathrm{~A}$
Thiago LRS, Gill M (1986) The effect of conservation method and frequency of feeding on the removal of digesta from the rumen. Proc Nutr Soc 45, 97A

Thomas C, Gill M, Austin AR (1980) The effect of supplements of fishmeal and lactic acid on voluntary intake of silage by calves. Grass Forage Sci 35, 275-279

Waldo DR, Miller RW, Okamoto M, Moore LA (1966) Ruminant utilization of silage in relation to hay, pellets and hay plus grain. II. Rumen content, dry matter passage and water intake. J Dairy Sci 43, 1478-1480

Wilkins RJ, Hutchinson $\mathrm{KJ}$, Wilson RF, Harris CE (1971) The voluntary intake of silage by sheep. 1. Interrelationships between silage composition and intake. J Agric Sci (Camb) $77,531-537$ 